\title{
Replying to "Questions and Concerns Re: Blue Water Footprints Reported in "Water Footprint of Meat Analogs: Selected Indicators According to Life Cycle Assessment"'"
}

\author{
Ujué Fresán ${ }^{1,2,3, *,+} \oplus$, D.L. Marrin ${ }^{4, \dagger}$, Maximino Alfredo Mejía ${ }^{1}$ and Joan Sabaté ${ }^{1}(\mathbb{C}$ \\ 1 Center for Nutrition, Healthy Lifestyles, and Disease Prevention, School of Public Health, \\ Loma Linda University, Loma Linda, CA 92350, USA; mmejia@andrews.edu (M.A.M.); jsabate@llu.edu (J.S.) \\ 2 CIBER Epidemiología y Salud Pública, Instituto de Salud Carlos III, 28029 Madrid, Spain \\ 3 Instituto de Salud Pública y Laboral de Navarra, 31003 Pamplona, Spain \\ 4 Water Sciences \& Insights, Encinitas, CA 92023, USA; marrin@watersciences.org \\ * Correspondence: ujuefresan@gmail.com \\ + First two authors contributed equally and are listed in arbitrary order.
}

Received: 16 April 2020; Accepted: 9 May 2020; Published: 12 July 2020

check for updates

\begin{abstract}
In 2019, we published a study focused on the quantification of several indicators related to the water footprint of meat analogs. Recently, a comment requesting clarification of specific data that were reported in our study was published. The present reply addresses their questions. We justified the high volume of water consumed in the production of the meat analogs' ingredients, the observed differences between our data and those reported for other plant-based products and the information we had reported in our original manuscript that was obtained from secondary sources in the scientific literature. We anticipate that our responses address the questions that were raised.
\end{abstract}

Keywords: meat substitutes; plant-based food; water footprint; water consumption; life cycle assessment

\section{Introduction}

Last year, Water journal published our paper quantifying several indicators related to the water footprint of meat analogs produced by a selected facility [1]. Table 1 summarizes the main findings of our original study. Mejia et al. described the methodology for the collection of data upon which that paper was based [2]. A comment was published asking for clarification of selected data reported in our study [3]. Specifically, the specified concerns identified three main issues: (1) water consumption estimates for the ingredients of our meat analog products, (2) differences between the water consumption estimates we reported and those reported by other publications assessing similar meat analogs, and (3) data cited in our paper reflecting water consumption of other food products, including both meat analogs and real meat products. The present comment is intended to address these points. 
Table 1. Mean (standard deviation) of water-related impacts attributable to different phases of meat analog production. Data for impact categories are reported per $\mathrm{kg}$ of final product.

\begin{tabular}{ccccccc}
\hline \multicolumn{7}{c}{ Per kg of Product } \\
\hline Impact Indicator & Units & Ingredients & Transportation Processing & Packaging & Total \\
\hline Blue water consumption & Liters & $944(449)$ & $12.2(6.86)$ & $2410(1004)$ & $425(472)$ & $3800(1240)$ \\
Freshwater eutrophication & g P eq. ${ }^{1}$ & $0.190(0.058)$ & $0.001(0.001)$ & $0.313(0.130)$ & $0.056(0.061)$ & $0.561(0.183)$ \\
Marine eutrophication & g N eq. $^{2}$ & $2.20(0.96)$ & $0.000(0.000)$ & $0.021(0.008)$ & $0.012(0.007)$ & $2.23(0.96)$ \\
Freshwater ecotoxicity & g 1,4-DCB eq. ${ }^{3}$ & $10.9(6.8)$ & $0.183(0.103)$ & $0.656(0.305)$ & $0.184(0.159)$ & $11.9(6.78)$ \\
Marine ecotoxicity & g 1,4-DCB eq. ${ }^{3}$ & $4.80(1.84)$ & $0.258(0.138)$ & $1.13(0.44)$ & $0.654(0.696)$ & $6.84(2.11)$ \\
\hline Using the ReCiPe 2016 impact assessment methodology. ${ }^{1}$ g P eq.: grams of phosphorus equivalents; ${ }^{2}$ g N eq.: \\
gram of nitrogen equivalents; ${ }^{3}$ g 1,4-DCB eq.: gram of 1,4-dichlorobenzene equivalents.
\end{tabular}

\section{Water Consumption of Ingredients Included in Meat Analogs}

We reported that 3800 liters (L) of water was consumed in the production of each kilogram of the meat analog. Of this amount, 35\% (944 L) corresponded to the agricultural production of the meat analogs' ingredients. As the authors of the comment pointed out, and as is also stated in the original paper, the term "water consumption" refers to blue water only. In general, life cycle assessment (LCA) inventories only account for blue water (i.e., ground and/or surface water sources), leaving out green water (rain water) from freshwater consumption [4,5]. Although this could be considered as an underestimation of the total water consumption, our study is consistent with other LCA studies relying on inventories that consider only the blue water irrigation of crops.

The recent comment highlighted the high value of the blue water footprint related to that phase of production. They cited Mekonnen and Hoekstra [6,7], who reported much lower values for unprocessed or minimally processed ingredients commonly included in meat analogs, such as soy (70 liters per kilogram $(\mathrm{L} / \mathrm{Kg})$ ), wheat $(342 \mathrm{~L} / \mathrm{Kg})$ and eggs $(244 \mathrm{~L} / \mathrm{Kg})$. They commented that they would be surprised if those highly processed plant-based ingredients had a sufficiently large water consumption to offset the values of the lesser processed ingredients.

Table 2 lists the different indicators related to the water footprint of the main ingredients comprising our meat analogs. For transparency, we not only provide information about blue water consumption, but also other water-related indicators such as freshwater and marine eutrophication and ecotoxicity. The water consumption of the products increases in proportion to their extent of processing. For example, the production of isolated soy protein consumed almost three-times more water than texturized soy protein and seven-times more than soybean oil, even though all three are derived from the same unprocessed ingredient, namely soybeans. Other reports have also identified isolated soy protein as highly water consumptive. For example, Berardy et al. [8] report that producing $1 \mathrm{~kg}$ of isolated soy protein required $38,950 \mathrm{~L}$ of water. This relatively high value is due to the increased consumption of soybeans to produce a highly-processed isolate instead of lesser-processed products, as well as water used to generate the energy needed for increased processing. Indeed, highly processed plant-based ingredients have been highlighted as having a greater impact on resources and the environment than their lesser-processed counterparts [9]. The highly-processed, soy-derived components of our reported products may be largely responsible for the water consumption value we reported in our paper [1]. 
Table 2. Water-related impacts attributable to $1 \mathrm{~kg}$ of the different ingredients included in the meat analogs, ranked by blue water consumption.

\begin{tabular}{|c|c|c|c|c|c|c|}
\hline \multicolumn{7}{|c|}{ Per kg of Product } \\
\hline & Impact Category & $\begin{array}{c}\text { Blue Water } \\
\text { Consumption }\end{array}$ & $\begin{array}{c}\text { Freshwater } \\
\text { Eutrophication }\end{array}$ & $\begin{array}{c}\text { Marine } \\
\text { Eutrophication }\end{array}$ & $\begin{array}{l}\text { Freshwater } \\
\text { Ecotoxicity }\end{array}$ & $\begin{array}{c}\text { Marine } \\
\text { Ecotoxicity }\end{array}$ \\
\hline & Unit & Liters & g P eq $^{1}$ & $\mathrm{~g} \mathrm{~N} \mathrm{eq}^{2}$ & g $1,4-\mathrm{DCB}^{3}$ & g $1,4-$ DCB $^{3}$ \\
\hline Product & Source of Information & & & & & \\
\hline Tap water & LCA Food DK & 1.096 & 0.000 & 0.000 & 0.000 & 0.000 \\
\hline Gluten & Own data & 6.176 & 0.271 & 6.540 & 8.873 & 9.480 \\
\hline Corn oil & Own data & 60.207 & 0.150 & 2.402 & 54.623 & 24.537 \\
\hline Soybean oil & US-EI 2.2 & 637.929 & 0.705 & 4.920 & 1.815 & 1.018 \\
\hline Egg white liquid & Own data & 759.711 & 0.372 & 11.194 & 0.245 & 1.175 \\
\hline Salt & US-EI 2.2 & 1035.269 & 0.152 & 0.037 & 0.305 & 1.111 \\
\hline Texturized soy protein & Own data & 1464.549 & 0.177 & 0.019 & 3.673 & 2.961 \\
\hline Modified starch & US-EI 2.2 & 3629.683 & 0.510 & 1.391 & 1.747 & 5.453 \\
\hline
\end{tabular}

Using the ReCiPe 2016 impact assessment methodology. ${ }^{1} \mathrm{~g}$ P eq.: grams of phosphorus equivalents; ${ }^{2} \mathrm{~g} \mathrm{~N}$ eq.: gram of nitrogen equivalents; ${ }^{3} \mathrm{~g}$ 1,4-DCB eq.: gram of 1,4-dichlorobenzene equivalents.

\section{Differences between the Water Consumption We Reported Versus the One Reported by Other Papers}

We previously reported that the total amount of water consumed in the production of $1 \mathrm{~kg}$ of meat analog was $3800 \mathrm{~L}$. Other studies have reported much lower values ranging from 19 to $44 \mathrm{~L} / \mathrm{Kg}$ [10]. However, it should be noted that this volume was measured as water use, which is not directly comparable to water consumption, as the indicator used in our analysis, by means of the ReCiPe 2016 methodology. "Water use" is defined as the use of water by human activity. Use includes, but is not limited to, any water withdrawal within the drainage basin impacting water flows and quality [4]. "Water consumption" is the water removed from, but not returned to the same drainage basin. Water consumption may be a result of evaporation, transpiration, product integration or release into a different drainage basin or the sea [4]. On one hand, water use typically includes the volume of water consumed minus the volume returned to the watershed, whereas on the other hand, water consumption does not consider any water as returned.

Values below $200 \mathrm{~L}$ for water consumed per kilogram of plant-based burger have been published elsewhere [11,12]. On one hand, the plant-based meat analogs requiring less water contain among their ingredients highly processed plant-based sources of protein from crops other than soy [11,12]. Recent investigations suggest that highly-processed ingredients obtained from rapeseed, lupin bean and yellow pea may be less water consumptive than the soy-derived ingredients that dominate the products we studied [9]. On the other hand, according to our assessment, in-factory activities contributed most to the total water consumption of the products $(2410 \mathrm{~L}$ as $55 \%$ of the total). We recognize this may represent an overestimate, as Mejia et al. [2] acknowledged that the in-factory energy requirement allocated to meat analog production not only included the actual food production, but also the supporting activities performed in the factory (e.g., lights used in offices). In any case, our products have a long history in the plant-based food market, and their manufacturing technology has not changed appreciably over the last century. The literature indicates recent efforts by the food industry to produce more sustainable products $[13,14]$. Hence, it is likely that the older production methods used for our products are less efficient, in terms of both water and energy, than are those more recently developed. These newer production technologies and more sustainable ingredients could explain the differences in water consumption between our products and similar ones that have been more recently introduced. 


\section{Data Published in the Literature}

The values for the water use of products that were based on the data from Dettling et al. [10] were incorrectly adjusted in an attempt to calculate a water use index that was more comparable to the water consumption index for the meat analogs in this study. Table 3 has been corrected and the associated discussion has been modified to reflect the non-adjusted water use values. In addition, we have modified the table so that water footprints for the unprocessed meats have been drawn exclusively from LCA studies rather than water footprint assessment (WFA) studies. As we discussed in the original paper [1], comparing values calculated from the WFA or even closely related LCA methodologies can be problematic as a result of the differences in the assumptions and algorithms employed to calculate those values [5]. As such, the WFA data presented by Berardy et al. [8] from the publications by Hoekstra [15] and Mekonnen and Hoekstra [16] have been removed. Additionally, the footnote explaining the values listed for unprocessed pork has been clarified as per your request.

\section{Conclusions}

We thank the authors for their comments [3] and for their interest in our study. We realize that some of our data may not have been adequately explained in light of similar studies appearing in the literature, and that the resulting differences may have been confusing to other readers. We also appreciate the correction to Table 3 and believe that our responses and revisions address the concerns that were raised. Finally, we have submitted a corrected version of Table 3 along with the text changes in the Discussion and Conclusion sections of the paper that are associated with the changes in the table. We anticipate these corrections will be published as an addendum to the original paper.

Funding: The original research was funded by the McLean Nutritional Research Endowment and administered by the Loma Linda University School of Public Health (https://publichealth.llu.edu/about/blog/alumni-endowments). The McLean Nutritional Research Endowment had no role in the design of the original study; collection, analysis and interpretation of the data; preparation of the manuscript; or the decision to publish the results. This reply did not receive funding and represents to collective views of the authors.

Acknowledgments: We would like to thank again the meat analog factory for allowing us to access their site, interview personnel and collect detailed production data.

Conflicts of Interest: The authors declare no conflict of interest.

\section{References}

1. Fresán, U.; Marrin, D.L.; Mejia, M.A.; Sabaté, J. Water Footprint of Meat Analogs: Selected Indicators According to Life Cycle Assessment. Water 2019, 11, 728. [CrossRef]

2. Mejia, M.A.; Fresán, U.; Harwatt, H.; Oda, K.; Uriegas-Mejia, G.; Sabaté, J. Life Cycle Assessment of the Production of a Large Variety of Meat Analogs by Three Diverse Factories. J. Hunger Environ. Nutr. 2019. [CrossRef]

3. Santo, R.; Kim, B.; Nachman, K. Questions and concerns re; blue water footprints reported in “Water Footprint of Meat Abnalogs Selected Indicators According to Life cycle Assessment". Water 2020, 20, 1270. [CrossRef]

4. $\quad$ Pieper, M.; Kupfer, T.; Thylmann, D.; Bos, U. Introduction to Water Assessment in GaBi version 2.2. 2018. Available online: https://www.gabi-software.com/fileadmin/Documents/Introduction_to_Water_Assessment_V2.2_03.pdf (accessed on 15 April 2020).

5. Boulay, A.-M.; Hoekstra, A.Y.; Vionnet, S. Complementarities of Water-Focused Life Cycle Assessment and Water Footprint Assessment. Environ. Sci. Technol. 2013, 47, 11926-11927. [CrossRef] [PubMed]

6. Mekonnen, M.M.; Hoekstra, A.Y. The green, blue and grey water footprint of crops and derived crop products. Hydrol. Earth Syst. Sci. 2011, 15, 1577-1600. [CrossRef]

7. Mekonnen, M.M.; Hoekstra, A.Y. The Green, Blue and Grey Water Footprint of Farm Animals and Animal Products, 2010b, UNESCO-IHE, Delft, the Netherlands. Available online: http://waterfootprint.org/media/ downloads/Report-48-WaterFootprint-AnimalProducts-Vol1.pdf (accessed on 15 April 2020).

8. Berardy, A.; Costello, C.; Seager, T. Life Cycle Assessment of Soy Protein Isolate. In Proceedings of the 100 International Symposium on Sustainable Systems and Technologies, Dearborn, MI, USA, 18 May 2015. 
9. Blonk Consultants. Revealing the Environmental Impact of Plant Proteins. Available online: https://www. blonkconsultants.nl/2017/12/14/revealing-the-environmental-impact-of-plant-proteins/?lang=en (accessed on 29 March 2020).

10. Dettling, J.Q.T.; Faist, M.; DelDuce, A.; Mandlebaum, S. A Comparative Life Cycle Assessment of Plant-Based Foods and Meat Foods; Quantis USA: Boston, MA, USA, 2016; Available online: https://www.morningstarfarms. com/content/dam/morningstarfarms/pdf/MSFPlantBasedLCAReport_2016-04-10_Final.pdf (accessed on 28 March 2020).

11. Goldstein, B.; Moses, R.; Sammons, N.; Birkved, M. Potential to curb the environmental burdens of American beef consumption using a novel plant-based beef substitute. PLoS ONE 2017, 12, e0189029. [CrossRef] [PubMed]

12. Khan, S.D.J.; Loyola, C.; Hester, J.; Moses, R. Environmental Life Cycle Analysis: Impossible Burger 2.0. Available online: https://impossiblefoods.com/mission/lca-update-2019/ (accessed on 28 March 2020).

13. Baldwin, C. Sustainability in the Food Industry; Wiley-Blackwell and the Institute of Food Technologists: Chicago, IL, USA, 2012. [CrossRef]

14. Yakovleva, N.; Flynn, A.; Green, K.; Foster, C.; Dewick, P. A Sustainability Perspective: Innovations in the Food System. In Proceedings of the Joint 4S/EASST Conference 2004 "Public Proofs—Sciences, Technology and Democracy", Paris, France, 25-28 August 2004.

15. Hoestra, A.Y. The water footprint of food. Water Food 2008, 49-60. Available online: https://waterfootprint. org/media/downloads/Hoekstra-2008-WaterfootprintFood.pdf (accessed on 12 May 2020).

16. Mekonnen, M.M.; Hoekstra, A.Y. A global assessment of water footprint of farm animal products. Ecosystems 2012, 15, 401-415. [CrossRef]

(C) 2020 by the authors. Licensee MDPI, Basel, Switzerland. This article is an open access article distributed under the terms and conditions of the Creative Commons Attribution (CC BY) license (http://creativecommons.org/licenses/by/4.0/). 